\title{
GORRESPONDENGE
}

The Editor,

\section{Journal of Glaciology}

SIR,

Note on the paper "Flexure of a floating ice tongue"

It has come to my notice that one of the analyses presented in my paper (Holdsworth, 1969) for the bending of an elastic model ice tongue is essentially the same as one given by Robin (1958). The works are independent but Robin's work takes precedence and I regret that his work was overlooked.

There is also a drafting error in Figure 4 (p. 390) of my paper where the distance $w_{\mathrm{a}}-w(x)$ should refer to the vertical height of the top surface of the ice tongue above the hydrostatic equilibrium position which corresponds to the "depressed position" at a large distance from the hinge line.

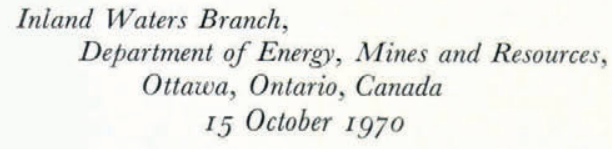

G. Holdsworth

\section{REFERENCES}

Holdsworth, G. r969. Flexure of a floating ice tongue. Fournal of Glaciology, Vol. 8, No. 54, p. 385-97.

Robin, G. de Q. 1958. Glaciology. III. Seismic shooting and related investigations. Norwegian-British-Swedish Antarctic Expedition, 1949-52. Scientific Results, Vol. 5.

Sir, Flexure of a floating ice tongue: comments on Dr G. Holdsworth's letter

I would like to express appreciation of Dr Holdsworth's letter. May I point out that Robin (1958) also presented some relevant observational data, which possibly remain the only relevant observational material available. The observations indicated that there was rough quantitative agreement between the elastic theory of bending and the position of tension cracks, the amount of surface stretching and the observed bending of the surface near the grounding line. There also appeared to be some non-elastic yielding of the ice to which attention was drawn and Holdsworth's paper contributes some new relevant theory on this point.

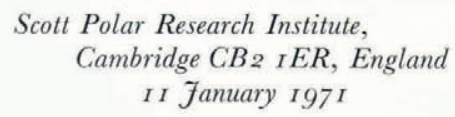

G. DE Q. RoBIN

\section{REFERENCE}

Robin, G. de Q. I958. Glaciology. III. Seismic shooting and related investigations. Norwegian-British-Swedish Antarctic Expedition, 1949-52. Scientific Results, Vol. 5.

SIR, Cold glaciers in the central Transantarctic Mountains, Antarctica: dry ablation areas and subglacial erosion

In the course of glacial geological work in the central Transantarctic Mountains in $1964-65$ and 1969-70 (Mercer, 1968, in press), I have observed some properties and activities of cold glaciers that may be of glaciological interest.

At high elevations, independent glaciers with permanently dry ablation areas occur; ablation is solely by sublimation, except perhaps for a small amount of mechanical deflation. An example of such a glacier (Fig. I) is on the north-west side of Heathcock Peak, in the Caloplaca Hills adjacent to Reedy Glacier (lat. $86^{\circ} \mathrm{o6}^{\prime} \mathrm{S}$., long. $130^{\circ} 4 \mathrm{o}^{\prime} \mathrm{W}$.; snout elevation about I $800 \mathrm{~m}$ ). No measurements were made on this glacier but, on a blue-ice distributary lobe of Reedy Glacier at a similar elevation, sublimation averaged $7.5 \mathrm{~mm}$ of ice/week between mid-November 1964 and mid-January 1965 . Because of the complete absence of run-off or surface melting, this is a more extreme type of polar glacier than Meserve Glacier in the Transantarctic Mountains of south Victoria Land (lat. $77^{\circ} 35^{\prime}$ S., long. $162^{\circ} 23^{\prime} \mathrm{W}$.; snout elevation $440 \mathrm{~m}$ ), where about $55 \%$ of the ablation is by sublimation (Bull and Carnein, 1970). 